\title{
Penguatan Solidaritas Sosial melalui FGD pada Santri di Pondok Pesantren Waria Al-Fatah Kotagede Yogyakarta
}

\author{
Strengthening Social Solidarity through FGDs for Santri \\ at the Al-Fatah Islamic Boarding School in Kotagede Yogyakarta
}

\author{
Dyaloka Puspita Ningrum \\ Program Studi Ilmu Komunikasi Universitas Widya Mataram, Yogyakarta, Indonesia \\ dyalokapuspita@yahoo.co.id
}

Riwayat Artikel: Dikirim 25 Juni 2021; Diterima 23 November 2021; Diterbitkan 30 November 2021

\begin{abstract}
Abstrak
Keberadaan waria sering dikonstruksikan sebagai kelompok marginal yang mengakibatkan munculnya sikap diskriminasi ditengah-tengah masyarakat. Disisi lain, fenomena yang menerpa kelompok waria tersebut bersinggungan juga dengan nilai-nilai humanis "bagaimana memanusiakan manusia" perlu mendapat dukungan tanpa adanya perbedaan antara satu sama lain berdasarkan isi Undang-Undang Dasar 1945 Pasal 28D mengenai Hak Asasi Manusia termasuk di Pondok Pesantren Waria Al-Fatah di Kotagede Yogyakarta yang terbentuk sejak tahun 2008 yang lalu. Kegiatan ini diikuti oleh 22 orang peserta dengan tujuan untuk memperkuat solidaritas sosial para santri dalam mencapai keharmonisan kelompok tersebut, terutama pada masa pandemi covid-19 sekarang. Menggunakan metode FGD / focus group discussion dan ceramah terkait pemahaman literasi media digital sebagai trend yang dapat diupayakan oleh para santri waria untuk membranding dirinya dan mempromosikan bisnisnya masing-masing secara lebih modern. Hasil kegiatan menunjukkan bahwa ada ketidaknyamanan yang ditemui para santri ketika beribadah di tempat umum, padahal kelompok tersebut memiliki kebutuhan yang sama seperti manusia lain, termasuk hasrat / dorongan spiritual. Sehingga melalui pondok pesantren inilah juga mereka diberikan ruang untuk beribadah dengan alasannya masing-masing. Adanya pengabdian kepada masyarakat di Pondok Pesantren Waria Al-Fatah diharapkan dapat semakin menguatkan toleransi dengan fokus kegiatan rohani antar umat beragama.
\end{abstract}

Kata kunci: Solidaritas Sosial, Keharmonisan, Pondok Pesantren Waria.

\begin{abstract}
The existence of waria is often constructed as a marginal group which results in the emergence of discriminatory attitudes in society. On the other hand, the phenomenon that hit the transgender group also intersects with the humanist values of "bow to humanize bumans" which need to be supported without any differences between each other based on the contents of the 1945 Constitution Article 28D concerning Human Rights, including at the Waria Al Islamic Boarding School. -Fatah in Kotagede Yogyakarta, which was formed in 2008. This activity was attended by 22 participants with the aim of strengthening the social solidarity of the students in achieving group harmony, especially during the current covid-19 pandemic. Using the FGD / focus group discussion method and lectures related to understanding digital media literacy as a trend that transgender
\end{abstract}


students can pursue to brand themselves and promote their respective businesses in a more modern way. The results of the activity show that there are discomforts encountered by the students when worshiping in public places, even though the group has the same needs as other humans, including spiritual desires / impulses. So that through this boarding school they are also given space to worship for their own reasons. The existence of community service at the Waria Al-Fatah Islamic Boarding School is expected to further strengthen tolerance with a focus on inter-religious spiritual activities.

Keywords: Social Solidarity, Harmony, Transgender Islamic Boarding School.

\section{PENDAHULUAN}

Dalam kehidupan sehari-hari manusia akan melakukan sebuah interaksi sosial untuk mencapai tujuannya masingmasing. Interaksi sosial diartikan sebagai proses timbal balik antara individu dengan individu, individu dengan kelompok atau kelompok dengan kelompok yang sangat dinamis (Narwoko, 2006:20).

Begitupun dalam kehidupan bermasyarakat terdapat sekumpulan individu yang secara khusus mengalami perbedaan identitas gender atau biasa disebut "Waria". Waria dikontruksikan sebagai kelompok marjinal. Menurut Koeswinarno (2004), secara fisiologis waria sebenarnya adalah pria. Namun pria (waria) ini mengidentifikasikan dirinya menjadi seorang wanita dalam tingkah laku keseharian. Seperti dalam penampilan atau dandanan, mereka mengenakan busana dan aksesori seperti wanita.

Begitupun dalam perilaku seharihari, mereka merasa dirinya sebagai seorang wanita yang memiliki sifat lemah lembut. Sehingga, kehadiran waria itu sendiri sering menjadi polemik di lingkungan sosial dan dianggap sebagai kelompok minoritas karena bertentangan dengan aturan, norma dan moral di masyarakat.

Minimnya toleransi untuk para waria yang ada di kota besar maupun di setiap daerah mengakibatkan terbatasnya pilihan pekerjaan yang dapat ditekuni oleh kelompok tersebut. Pada umumnya ada beberapa profesi yang biasa dilakukan oleh para waria dalam mencukupi kebutuhannya, mulai dari : pekerja salon, penjahit, pengamen, tukang masak, tukang pijat atau bahkan sebagai pekerja prostitusi di jalanan. Latar belakang tersebutlah yang juga semakin menambah deretan stigma negatif pada kelompok waria di Indonesia.

Krisis identitas yang dimilikinya, menghadirkan banyak hambatan sosial yang kadang hanya dipandang sebelah mata dan akhirnya berorientasi pada sebuah diskriminasi. Herdiansyah (2007) mengatakan bahwa keberadaan waria yang mengalami penolakan di lingkungan masyarakat maupun di dalam keluarga karena berperilaku menyimpang dapat memberikan permasalahan serius berupa beban serta kecemasan pada personality-nya.

Disisi lain, fenomena yang dihadapi kelompok waria bersinggungan dengan nilai-nilai humanis "bagaimana memanusiakan manusia” yang juga perlu mendapat dukungan tanpa adanya perbedaan antara satu sama lain sebagai Warga Negara Indonesia yang utuh berdasarkan isi Undang-Undang Dasar 1945 Pasal 28D mengenai Hak Asasi Manusia, termasuk komposisi dari kelompok waria yang ada di Pondok Pesantren Waria AlFatah Kotagede Yogyakarta.

Kelompok Waria Yogyakarta / IWAYO (Ikatan Warna Yogyakarta) yang anggotanya berasal dari berbagai daerah, usia, perekonomian yang terbatas, maupun keyakinan dianut yang berbeda-beda, tergabung menjadi satu-kesatuan di dalam Pondok Pesantren Waria Al-Fatah dengan fokus kegiatan spiritual yang sudah terbentuk sejak tahun 2008 lalu. Sebagai insan biasa, para waria di tempat ini perlahan-lahan belajar mendekatkan diri dan 
beribadah secara nyaman kepada Sang Pencipta.

Keberadaan Pondok Pesantren

Waria Al-Fatah perlahan-lahan berusaha untuk mengembalikan citra positif kelompok marginal tersebut di tengahtengah masyarakat. Di tahun 2020, Pondok Pesantren Waria Al-Fatah telah memiliki santri sebanyak 40 orang yang terdiri dari kalangan dewasa, orang-tua dan bahkan lansia. Seiring berjalannya waktu, para waria juga diberikan pendampingan rohani secara langsung oleh beberapa tokoh ulama sebagai figur yang berkompeten di kajiannya.

\section{Gambar 1:}

Pelataran Depan Pondok Pesantren Waria Al-Fatah Kotagede Yogyakarta

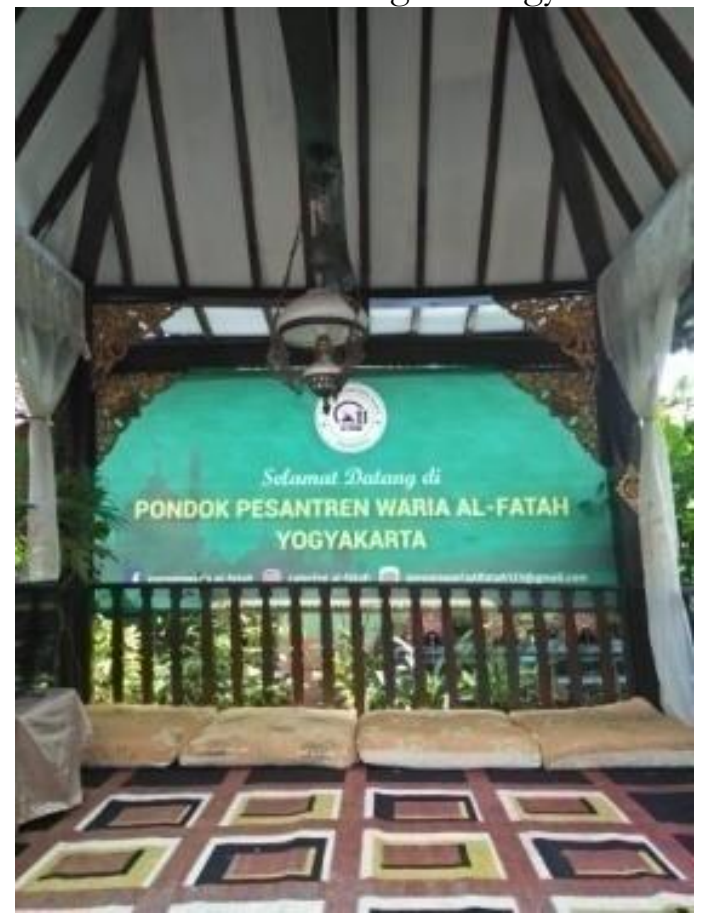

Sumber: Dokumen Pribadi

Senyatanya sebuah kelompok sosial, para waria itu sendiri menyadari bahwa dirinya merupakan bagian dari ikatan masyarakat. Sudah banyak program pemberdayaan yang dijalankan oleh Pondok Pesantren Waria Al-fatah khususnya pada keikutsertaan para santri di beberapa tradisitradisi lokal, seperti : memandikan jenazah, gotong royong, bakti sosial, serta pelatihan keterampilan di berbagai bidang (seperti : tata boga, tata rias/make-up, industri kreatif dan lainnya) diharapkan dapat menjadi solusi dan menggeserkan pandangan negatif di mata masyarakat.

Perjuangan para santri di Pondok Pesantren Waria Al-Fatah yang semakin mandiri terutama pada kegiatan keagamaan ternyata mampu mengantarkan kelompok ini mendapatkan penghargaan / pengakuan nasional dan bahkan internasional. Meskipun dengan keterbatasan Pandemi Covid-19 yang melanda dunia, membuat ruang gerak untuk para santri waria itu sendiri semakin sempit dalam berinteraksi di masyarakat. Hal ini disampaikan langsung oleh salah satu pengurus Pondok Pesantren Waria Al-Fatah yaitu Bunda Shinta Ratri selaku ketua (ditemui pengabdi pada tanggal 3 Desember 2020) bahwa :

"Menjalin kerjasama dan sering mendapat kunjungan dari beberapa Lembaga / Perguruan Tinggi sebenarnya dapat meningkatkan kepercayaan, spirit dan solidaritas kelompok tersebut. Namun memang wabah yang terjadi sekarang ini turut berimbas kepada aktivitas para santri di Pondok Pesantren Waria Al-Fatah, sehingga membuat kelompoknya mengalami kegelisahan / kekhawatiran untuk mengembangkan diri ataupun bertahan hidup ke depannya".

Di masa pandemi inilah juga, pembatasan sosial aktivitas masyarakat atas aturan yang ada. Membuat hubungan dan jalinan komunikasi diantara para santri satu dengan yang lain, terutama yang tidak menetap di tempat tersebut semakin kurang harmonis, sehingga berpengaruh terhadap solidaritas kelompok waria itu sendiri.

$$
\text { Menurut Gerungan }
$$
solidaritas yang tinggi terbentuk karena kepercayaan anggota- anggota di dalam kelompok terhadap kemampuan anggota lain dalam melaksanakan tugasnya dengan baik. Kepercayaan tersebut sangat 
dipengaruhi oleh pengalaman-pengalaman anggota kelompok dan situasi yang sulit. Semakin tinggi solidaritas kelompok maka semakin efektif juga kelompok tersebut dan membuat kelompok itupun semakin kokoh.

Berdasarkan kondisi tersebutlah, maka dibutuhkan sebuah kegiatan yang sifatnya tidak hanya informatif saja melainkan juga partisipatif untuk kelompok marginal yang ada di Pondok Pesantren Waria Al-Fatah Kotagede Yogyakarta agar dapat menciptakan peluang atas potensi yang dimiliki para santri waria dalam memenuhi kebutuhan hidupnya. Pendekatan humanis dijadikan dasar untuk menyamaratakan derajat kelompok waria di masyarakat agar semakin memperat hubungan sosial antara satu individu dengan yang lain.

\section{Tujuan Pengabdian}

Berdasarkan konsep yang telah diuraikan diatas, maka tujuan pengabdian kepada masyarakat ini adalah untuk memperkuat solidaritas sosial para santri waria yang ada di Pondok Pesantren Waria Al-Fatah Kotagede Yogyakarta dalam mencapai keharmonisan kelompoknya.

\section{METODE}

Kelompok sasaran kegiatan pengabdian kepada masyarakat ini adalah anggota / santri di Pondok Pesantren Waria Al-Fatah Kotagede Yogyakarta yang berjumlah 22 orang. Peserta yang ikut hanya sebagian dari total keseluruhan yang ada, dikarenakan kondisi pandemi yang terjadi saat ini tidak memungkinkan untuk menciptakan kerumunan massa dalam suatu acara.

Menggunakan metode focus group discussion dengan analisis SWOT (Strengths (kekuatan),Weaknesses (kelemahan), Opportunities (peluang), dan Threats (ancaman)) penyampaian materi kegiatan diaplikasikan melalui perkenalan, memetakan potensi dan identifikasi permasalahan yang dihadapi oleh para santri waria. Selain itu, ketua pengabdi juga memberikan ceramah terkait pemahaman mengenai literasi media digital yang dapat dimanfaatkan secara maksimal di industri kreatif sekarang ini, mulai dari : pengenalan jenis media sosial yang berpotensi untuk mendukung aktivitas para santri, manfaat dan pengaruh media tersebut, maupun aktivitas terkini yang dapat dijadikan konten ekonomis para santri yang bernilai jual.

Untuk semakin melengkapi kegiatan pengabdian kepada masyarakat di lokasi tersebut, evaluasi terhadap pencapaian apa saja yang sudah didapatkan sebelumnya oleh para santri menjadi langkah terakhir yang dilakukan sebagai acuan untuk melakukan kegiatan sejenis lainnya dimasa yang akan datang.

\section{HASIL DAN PEMBAHASAN}

Kegiatan pengabdian kepada masyarakat pada Program Studi Ilmu Komunikasi Fakultas Ilmu Sosial dan Ilmu Politik Universitas Widya Mataram Yogyakarta dengan tema "Upaya Memperkuat Solidaritas Sosial Untuk Keharmonisan Kelompok Marginal di Pondok Pesantren Waria Al-Fatah Kotagede Yogyakarta" dilaksanakan pada Rabu 7 April 2021 pukul 10.30 - 13.30 WIB, dan diikuti oleh 22 peserta yang terdiri dari para santri waria (usia 35-65 tahun) di tempat tersebut, mahasiswa magang dari Universitas Islam Negeri Sunan Kalijaga Yogyakarta, serta beberapa mahasiswa internal yang sengaja dilibatkan dalam kegiatan tersebut.

Sebelum kegiatan pengabdian kepada masyarakat dilaksanakan, ketua pengabdi terlebih dahulu melakukan survei dengan membuat janji via instant messaging kepada ketua pondok pesantren untuk menjadi narahubung dan mengundang beberapa santri lainnya yang tidak menetap di tempat tersebut. 
Gambar 2:

Pembukaan kegiatan pengabdian kepada masyarakat di Pondok Pesantren Waria Al-

Fatah Kotagede Yogyakarta

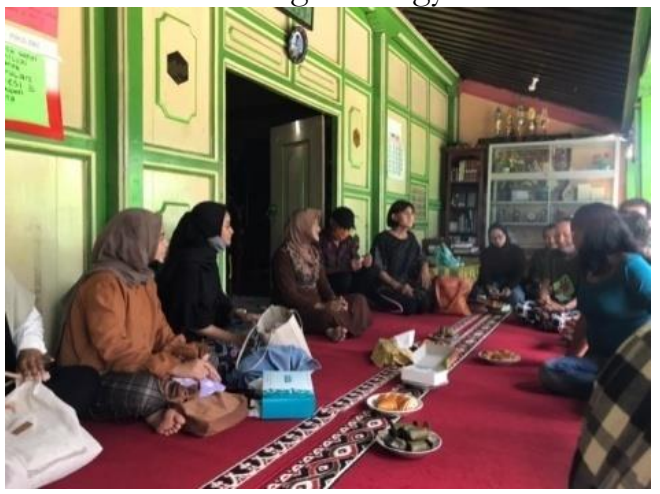

Sumber: Dokumen Pribadi

Dalam rangka memenuhi tugas wajib Tri Dharma Perguruan Tinggi di tahun 2021, kegiatan pengabdian kepada masyarakat di Pondok Pesantren Waria AlFatah Kotagede Yogyakarta dilaksanakan dengan persiapan semaksimal mungkin guna menghindari hal-hal yang kontradiktif dengan ketentuan di masa adaptasi kebiasaan baru sekarang ini.

Untuk mempersingkat waktu, ketua pengabdian sengaja mengatur alur kegiatan dengan durasi yang tidak begitu lama dilokasi tersebut, guna menghindari kontak secara langsung di satu tempat yang sama. Pertemuan diawali dengan perkenalan anggota tim dan dilanjutkan dengan focus group discussion / FGD yang dilakukan dengan cara yang amat sederhana mengingat pertimbangan dari mitra sendiri yang mengungkapkan bahwa lokasi pengabdian hanya memiliki lahan / kawasan yang tidak begitu luas.

Prosesi FGD dibagi sebanyak 3 tim, yang mana disetiap timnya sendiri terdiri dari mentor yang merupakan 2 orang santri di Pondok Pesantren dan 3-4 orang mahasiswa yang dipilih secara acak sebagai anggota kegiatan dan berlangsung selama kurang lebih 1 jam-an. Setiap mentor secara bergantian membagikan pengalaman pribadinya masing-masing, mulai dari : daerah asal, tempat tinggal saat ini, penerimaan keluarga terhadap identitas dirinya, pekerjaan yang dijalani, pasangan hidup, persoalan yang dihadapi, motif bergabung di pondok pesantren waria, ataupun harapan dimasa yang akan datang. Diskusi tersebut berjalan sangat lancar karena disambut juga dengan ketertarikan dan rasa keingintahuan yang tinggi dari para mahasiswa yang hadir.

Pada sesi PGD itulah juga, berbagai masalah sosial maupun ekonomi yang menghimpit para santri disampaikan. Dalam rangka memutus angka penyebaran Virus Corona di Kota Jogja, secara sederhana ketua pengabdi pun sangat mendukung kebijakan protokol kesehatan dengan cara membagikan masker dan terus mengingatkan para peserta untuk rutin menggunakan handsanitizer atau sekedar mencuci tangan.

Seiring waktu diakui para santri bahwa kehadiran Pondok Pesantren Waria Al-fatah Kotagede Yogyakarta menjadi tempat akhir persinggahan mereka untuk lebih mendekatkan diri kepada Tuhan Yang Maha Esa. Uniknya, ada 2 fenomena yang dijalani para santri waria ketika sedang beribadah, khususnya untuk umat muslim, yaitu : (1) waria yang memilih untuk tetap menggunakan sarung, dan (2) waria yang menggunakan mukenah, dengan alasannya masing-masing.

Super penting lainnya yang harus dipahami oleh masyarakat luas, terkait keberadaan pondok pesantren tersebut yang tidak hanya mendominasi terhadap satu keyakinan saja, namun justru saling mengayomi antara satu sama lain, sehingga sangat berpengaruh pada solidaritas kelompok yang sering ditunjukkan dengan sikap saling membantu, saling peduli, dan saling memberdayakan, meskipun para santri di pondok pesantren al-fatah sendiri sebagian besar merupakan orang-orang yang berasal dari luar kota Jogja. Ada beberapa kegiatan rutin juga yang sering dilakukan para santri khususnya sebelum terjadi 
pandemi, misal : pengajian dan tausiah yang mengundang ulama untuk umat muslim, ibadah kerohanian mengundang pendeta / pastur untuk umat nasrani, adanya kelas psikologi, maupun olahraga rutin seperti senam pagi setiap bulannya. Hal tersebutlah yang juga menjadi poin pendukung terhadap analisis SWOT untuk para santri khususnya pada aspek kekuatan kelompok.

Gambar 3:

Visualisasi FGD di lokasi kegiatan
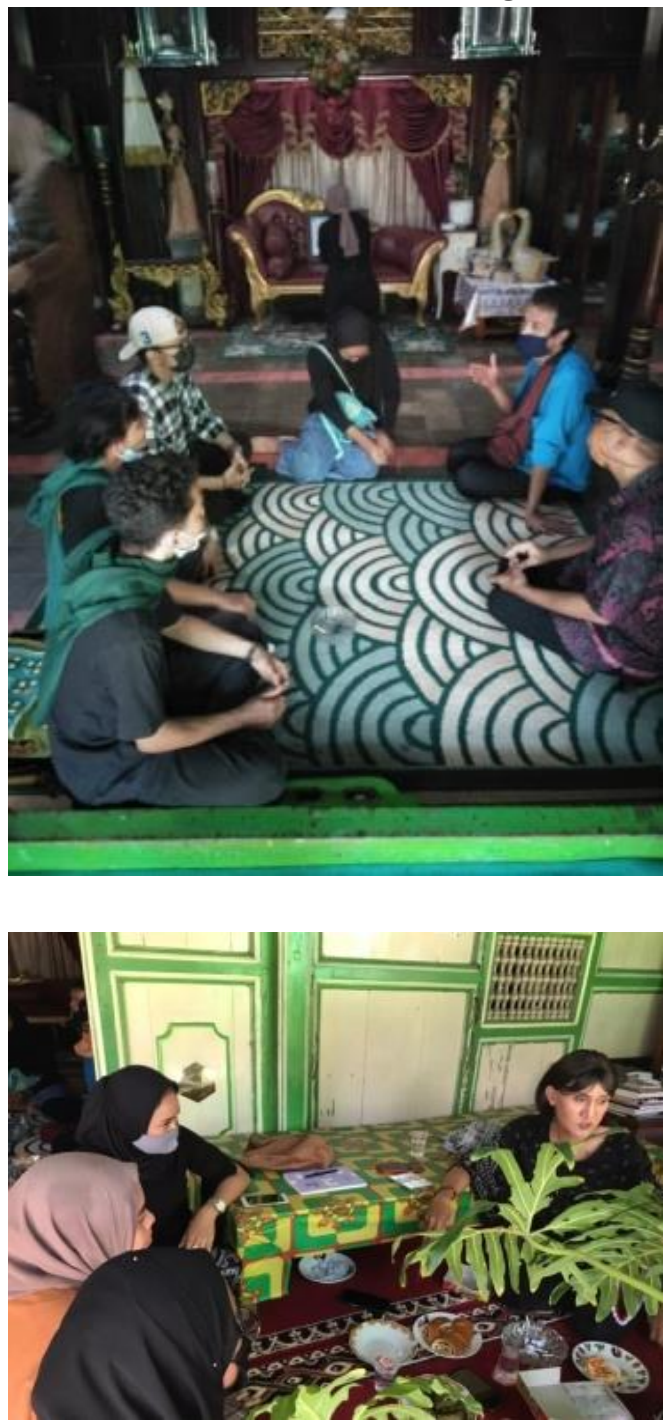

Sumber: Dokumen Pribadi

Dengan adanya FGD itupun diharapkan dapat menjadi salah satu ruang untuk meminimalisir tendensi sosial seperti bullying, stereotip, ataupun hanya sekedar bisik-bisik yang melemahkan para santri dalam beribadah dan berinteraksi di masyarakat pada umumnya.

Tidak ketinggalan pada kesempatan itu juga, ketua pengabdi yang berperan sebagai fasilitator bahkan memberikan sesi tanya jawab antara mentor dengan anggota kegiatan guna menciptakan sikap responsif dengan tetap mengedepankan nilai-nilai humanis. Beberapa celotehan / "guyonan" dari para santri ataupun para anggota turut meramaikan kegiatan tersebut, untuk tetap menciptakan susasana yang terkesan santai

Sikap kepemimpinan dimasa kepengrusan yang pertama yaitu Ibu Maria (Alm) dan bahkan yang sekarang oleh Bunda Sinta, sangat dirasakan oleh para santri waria untuk terus menjadi kesatuan keluarga di tempat tersebut maupun tercapainya perubahan hidup yang lebih baik lagi.

Secara kepribadiaan pun ada banyak dampak positif yang didapatkan para santri waria terutama dalam hal kepercayaan diri maupun pekerjaan yang lebih layak dari sebelumnya, meskipun tidak dapat dipungkiri bahwa setiap individu yang ada di dalamnya rata-rata memiliki keterbatasan ekonomi dan pendidikan yang kurang memadai.

Untuk semakin membedah proses FGD, ditemukan permasalahan yang cukup krusial khususnya terkait jalinan komunikasi dan hubungan antarpersonal para santri satu dengan yang lain, ternyata menunjukkan kondisi yang kurang harmonis, terutama di masa pandemi. Kondisi sekarang sangat mengharuskan setiap individu untuk cakap teknologi, namun kenyataan yang ada di tempat tersebut sebagian besar anggota Pondok Pesantren yang rata-rata berusia lansia, masih belum dapat mengoperasionalkan handphone dengan maksimal, disamping ketiadaan kuota dan faktor pendukung lainnya. Menyoroti hal ini sama seperti aspek kelemahan terhadap 
analisis SWOT yang tercipta secara alamiah diantara para santri waria.

Untuk memaksimalkan rangkaian acara yang sudah disusun secara keseluruhan, ketua pengabdi kembali melanjutkan kegiatan tersebut dengan mengambil alih dalam memandu acara ke sesi berikutnya. Hasil FGD sendiri dirangkum dengan analisis SWOT yang tentu saja disandingkan juga dengan trend saat ini, terutama terkait pemahaman dan pemanfaatan media digital sebagai ruang publik yang sangat potensial.

Sebuah literasi media digital menjadi topik pilihan yang disampaikan ketua pengabdi, khususnya dalam pengoptimalan media sosial (instagram dan tiktok) yang dapat digunakan untuk membranding diri maupun mempromosikan bisnis / usaha yang dijalankan oleh para santri waria, seperti : catering makanan, makeup pengantin, kursus menari \& menyanyi, dan lain sebagainya. Karena memang, sejauh ini berdasarkan pengakuan dari para santri waria tersebut, mereka belum mampu untuk mengoperasionalkan platform digital, termasuk juga membuat jenis konten apa yang akan dibagikan secara rutin kepada pengguna lainnya.

Kegiatan pemasaran yang dilakukan para santri waria sampai saat ini hanya menggunakan model yang masih sangat konvensional, sehingga dengan bekal FGD maupun ceramah terkait literasi media digital tersebut bisa menjadi gerbang awal untuk mulai memasuki pasar online yang sudah sangat mainstream keberadaannya.

Akhirnya ketua pengabdi mengarahkan setiap santri waria untuk produktif dan aktif di media sosial, khususnya dalam hal ini mereka langsung membuat email dan akun di media sosial instagram untuk dapat memasarkan bisnisnya masing-masing. Mengingat juga, ada beberapa bantuan sosial yang telah didapatkan oleh para pengurus dari berbagai pihak eksternal sebagai program peningkatan kesejahteraan para santri waria di tempat tersebut.

Dengan adanya media sosial pribadi yang telah dibuat pada sesi sebelumnya, diharapkan juga dapat semakin meningkatkan keterampilan dan potensi yang dimiliki para santri untuk dapat bersaing di pasar global terutama dengan berbagai cara yang kreatif, seperti halnya aspek peluang pada analisis SWOT yang dapat dimanfaatkan semaksimal mungkin.

Penerimaan masyarakat luas terhadap keberadaan kelompok waria menjadi harapan besar para santri untuk semakin memiliki rasa percaya diri dalam berinteraksi dan bahkan perlahan-lahan menyembuhkan krisis identitas yang dimilikinya.

Kegiatan terakhir diisi dengan meyakinkan para santri waria untuk terus optimis dan saling menjaga silaturahmi diantaranya. Termasuk juga membangun keyakinan para santri untuk bisa mendapatkan program vaksinasi covid-19 yang diberikan oleh pemerintah di fase sekarang. Lemahnya kerja sama yang terbentuk atas dasar kepentingan ekonomi masing-masing, masih menjadi ancaman untuk kelompok waria di Kota Jogja, terutama para waria yang belum terbina di lokasi tersebut.

Sudah banyak pihak dari berbagai lembaga / instansi yang datang ke tempat tersebut. Namun persoalan terkait penggunaan media sosial secara khusus belum menjadi fokus implementasi yang diwujudkan untuk membangun citra diri dan memasarkan produk / jasa yang dimiliki, khususnya oleh para santri waria. Sehingga memberikan literasi terkait penggunaan, manfaat maupun potensi pasar di media digital menjadi strategi pendekatan yang dilakukan dalam kegiatan tersebut. 
Menutup jalannya kegiatan pengabdian kepada masyarakat, evaluasi pun turut dilakukan oleh ketua pengabdi terhadap beberapa mahasiswa internal yang sengaja diajak ke lokasi tersebut. Karena memang diakui para anggota tim bahwa kegiatan inipun menjadi pengalaman pertama mereka secara personal dalam berinteraksi secara dekat dengan para santri waria. Sehingga konfirmasi yang dituangkan dalam bentuk pertanyaan oleh ketua pengabdi, berguna untuk meminimalisir prasangka buruk terhadap kelompok waria dimanapun mereka berada.

\section{KESIMPULAN}

Kegiatan pengabdian kepada masyarakat di Pondok Pesantren Waria AlFatah Kotagede Yogyakarta berlangsung dengan cukup lancar. Para peserta yang terdiri dari santri waria, mahasiswa magang, maupun anggota tim terlihat dapat saling berkoordinasi antara satu sama lain. Interaksi secara langsung dimasa pandemi memang menimbulkan banyak kecemasan. Namun utamanya harus tetap disikapi dengan bijak, salah satunya dengan tetap mengedepankan protokol kesehatan disetiap aktivitas manusia.

Adanya ruang diskusi dianggap para santri waria sebagai bagian dari upaya untuk menekan sikap diskriminasi terhadap kelompok tersebut, salah satunya adanya keyakinan dari pihak luar yang mau menerima / berdiskusi bersama mereka.

Pondok Pesantren Waria Al-fatah Kotagede Yogyakarta adalah salah satu dari sekian banyak tempat yang dapat diambil dampak positifnya untuk menguatkan toleransi dengan fokus kegiatan rohani antar umat beragama. Karena bagaimanapun ukuran hidup manusia bukan ditentukan oleh jenis pakaian ataupun orientasi seksual saja, melainkan bagaimana setiap individu dapat menjaga laku hidupnya dan melakukan ibadah terhadap Tuhan Yang Maha Esa ataupun sesama antarmanusia.
Sehingga sebagai satu kesatuan bangsa yang utuh, sudah seharusnya antarmanusia dapat saling menghargai dan memberikan kenyamanan satu sama lain termasuk pada kelompok waria.

Pemberdayaan kelompok waria yang memiliki keahlian dan keterampilan khusus bisa diupayakan oleh semua pihak guna menciptakan sumber daya manusia yang berkualitas dan professional.

\section{DAFTAR PUSTAKA}

A, Gerungan W. 2002. Psikologi Sosial. Bandung: Refika aditam

Bagong - Dwi Narwoko, J. (2006). Sosiologi Teks Pengantar dan Terapan. Jakarta : Kencana Media Group

Herdiansyah. (2007). Kecemasan dan strategi coping waria pelacur. Jurnal Ilmiah Berkala Psikologi, 9(1), 96-107. https://publikasiilmiah.ums.ac.id/bi tstream/handle/11617/1408/7Haris _Vol $\% 209 \% 20 \mathrm{No} \% 201 \% 20 \mathrm{Mei} \%$ 202007.pdf?sequence $=1 \&$ is Allowed $=\mathrm{y}$

Koeswinarno (2004). Hidup sebagai waria. Yogyakarta: LkiS

VOA (2019). Waria Al-Fatah Kotagede Fokus Pada peningkatan Kualitas Hidup Waria. https://www.voaindonesia.com/a/p esantren-al-fatah-kotagede-fokus-padapeningkatan-kualitas-bidupwaria/4941117.html. Diakses pada tanggal 7 Desember 2020

Tempo.CO (2019). Pemimpin Pesantren Waria Yogya Terima Penghargaan Pembela HAM. https://nasional.tempo.co/read/12 26461/pemimpin-pesantren-waria-yogyaterima-penghargaan-pembela-ham.

Diakses pada tanggal 7 Desember 2020 